\title{
Harold C Simmons Cancer Center
}

National Cancer Institute

\section{Source}

National Cancer Institute. Harold C Simmons Cancer Center. NCI Thesaurus. Code C105623.

The Harold C Simmons Cancer Center is focused on translational cancer research. It became an NCl-designated cancer center in 2010. It is part of University of Texas Southwestern Medical Center. 